\title{
Lysogeny and prophage induction in coastal and offshore bacterial communities
}

\author{
Markus G. Weinbauer ${ }^{1}$, Curtis A. Suttle ${ }^{2, *}$ \\ ${ }^{1}$ National Research Centre for Biotechnology, Division of Microbiology, Mascheroder Weg 1, D-38124 Braunschweig, Germany \\ ${ }^{2}$ Departments of Earth and Ocean Sciences (Oceanography), Botany and Microbiology \& Immunology, \\ University of British Columbia, 6270 University Boulevard, Vancouver, British Columbia V6T 1Z4, Canada
}

\begin{abstract}
The influence of solar radiation and hydrogen peroxide on induction of lysogens, and the resulting effect on bacteriophage production and bacterial mortality was investigated for coastal and oceanic marine bacterial communities at 6 stations in the western Gulf of Mexico. The percentage of lysogenic cells induced by mitomycin $\mathrm{C}$ was also determined. Solar radiation and hydrogen peroxide were not as effective as mitomycin $\mathrm{C}$ at inducing phage production. The burst size of cells induced by mitomycin $C$ was estimated by transmission electron microscopy, assuming that cells completely filled with viral particles were on the verge of bursting. The smallest estimates of burst size were associated with oligotrophic oceanic stations and ranged from 15 to 28 viruses produced per lytic event, while in more productive coastal waters the estimated burst sizes ranged from 33 to 64 . The mitomycin $\mathrm{C}$ induced phage production and burst size were used to estimate the number of lysogenic bacterial cells. On average, the percentage of inducible lysogens was higher at offshore ( 1.5 to $11.4 \%$ ) than at coastal $(0.8$ to $2.2 \%)$ stations. However, with the exception of 1 station, less than $5 \%$ of the bacteria could be induced to produce phage, suggesting that lysogens only occasionally comprised a significant component of these bacterial communities. The proportion of lysogens that could be induced by sunlight, relative to those that could be induced by mitomycin $C$. was lower at oceanic than coastal stations. This implies that prophages in optically transparent offshore waters were more resistant to induction by solar radiation, or that most lysogens that could be triggered by sunlight were already induced. Based on a steady-state model, induction of lysogenic bacteria by solar radiation or hydrogen peroxide could result in between 0 and $3.5 \%$ or 0.9 and $3.4 \%$ of the total bacterial mortality, respectively. Our results imply that solar radiation and hydrogen peroxide induced lysogenic phage production were not an important source of phage production or bacterial mortality in offshore or coastal waters of the western Gulf of Mexico.
\end{abstract}

KEY WORDS: Lysogeny $\cdot$ Prophage $\cdot$ Marine viruses $\cdot$ Bacteriophage $\cdot$ UV radiation

\section{INTRODUCTION}

Viruses are abundant and dynamic components of aquatic microbial food webs. They cause mortality of microorganisms, which can affect community composition and cycling of organic matter (Fuhrman \& Suttle 1993. Thingstad et al. 1993). The role of viruses in microbial food webs depends on their mode of replication. There are 2 major pathways of phage replication (Luria \& Darnell 1967). In the lytic cycle, the phage genome replicates immediately after infection and

•Addressee for correspondence.E-mail: suttle@eos.ubc.ca newly formed virus particles are released during lysis of the host cell. In the lysogenic cycle, the genome of a temperate phage integrates into the host genome where it is carried in a dormant form (prophage) until the lytic cycle is induced by factors such as exposure to UV. Thus, lytic phage production depends on encounter rates between phages and host cells, whereas, lysogenic phage production depends on the number of lysogenized cells in the bacterial community and on the presence of an inducing agent.

Hypotheses have been put forward to explain the advantages of lysogeny (e.g. Steward \& Levin 1984). For example, since lysogenized cells are immune 
against infection by phages that are closely related to the prophage, they may have a competitive advantage over non-lysogenized cells. Lysogeny is also a potential survival strategy to maintain phage populations when host abundance is too low for populations to be maintained by lytic infection. As well, temperate phages can add metabolic properties to bacterial strains, such as antibiotic resistance and production of virulence factors (Waldor \& Mekalanos 1996). In some temperate phages, low nutrient concentrations and a high ratio of viruses to host cells seems to favour the establishment of lysogeny; however, evidence for this is sparse for marine microbial communities (Wilson \& Mann 1997).

It has been suggested that lysogenic bacteria predominate in planktonic systems (Thingstad et al. 1993. Bratbak et al. 1994). Moebus (1983) found that about $10 \%$ of the phages isolated from marine systems were temperdie, while Jiang \& Paui (1994) were able to induce $43 \%$ of marine bacterial isolates to produce phage. A lower percentage of isolates from eutrophic than coral-reef and reef-lagoon environments could be induced. In other studies, Paul and co-workers detected lysogeny in ca $50 \%$ of marine samples (Jiang \& Paul 1996, Cochran \& Paul 1998, Cochran et al. 1998). In contrast, Weinbauer \& Suttle (1996) found lysogeny in all samples, but estimated that $<5 \%$ of bacteria in coastal waters were lysogenized. Wilcox \& Fuhrman (1994) found no evidence for lysogenic bacteriophage production in natural bacterial communities from coastal seawater, while in oligotrophic Lake Superior, Tapper \& Hicks (1998) estimated 0.1 to $7.4 \%$ of bacteria in natural communities were lysogenized. Current evidence suggests that lysogenic cells typically comprise a small proportion of bacteria in natural communities, but occasionally can be abundant.

Mitomycin C and UV-C are commonly used to induce lysogens (Ackermann \& DuBow 1987). Based on studies in the phage lambda (Gottesman \& Oppenheim 1994), mitomycin C and UV-C damage the DNA, which activates the SOS repair system, including the enzyme RecA. The RecA protein cleaves a repressor and induces the lytic cycle.

The factors that induce lysogenic phage production in nature are largely unknown. Solar radiation causes DNA damage in bacterioplankton (Aas et al. 1996, Jeffrey et al. 1996) and may be an inducing agent. Also, hydrogen peroxide can induce lysogenized cells by damaging the host DNA (Lwoff 1952, Ackermann \& DuBow 1987, Imlay \& Linn 1987). Because this molecule occurs in seawater (Van Baalen \& Marler 1966. Zika et al. 1985), it might be an inducing agent in nature. Increases in temperature and vigorous cell growth are also known to induce the lytic cycle (Gottesman \& Oppenheim 1994), and polyaromatic hydrocarbons can induce lysogens in natural bacterial communities (Jiang \& Paul 1996).

Potentially, increased UV-B in the upper layer of the ocean because of atmospheric ozone depletion (Jones \& Shanklin 1995) would result in higher induction rates of lysogens. In turn, this may affect species composition and the way viruses influence cycling of nutrients and trace gases. Elevated UV-B would also potentially increase induction rates via hydrogen-peroxide production from photodegradation of organic matter (Petasne \& Zika 1987, Johnson et al. 1989). Our study estimated the percentage of lysogens that could be induced by mitomycin C, solar radiation and hydrogen peroxide along a transect from oceanic to neritic waters in the western Gulf of Mexico. Sunlight effects on virus production and bacterial mortality were also investigated.

\section{MATERIALS AND METHODS}

Study sites and sampling. This study was done during cruises in the western Gulf of Mexico on June 20 to 28 (Stns A to F), and November 1, 1995 (Stn J, Fig. 1). Before sunrise, water for incubations was pumped from the surface $(0.5 \mathrm{~m}$ depth) or collected from the deep chlorophyll maximum (DCM; $72 \mathrm{~m}$ at Stn E) using Niskin bottles mounted on a rosette equipped with a Sea-Bird CTD (model SBE plus) and fluorometer. The depths of the DCM and mixed layer were determined from multiple profiles of salinity, temperature and fluorescence. Duplicate samples for viral and bacterial abundances, and burst size were preserved with glutaraldehyde ( $2 \%$ final concentration) immediately after collection, and stored in the dark at $4^{\circ} \mathrm{C}$. Samples for chlorophyll a (chl a) were collected onto $0.45 \mu \mathrm{m}$ pore-size filters and frozen for subsequent analysis.

Incubations. Freshly collected seawater (4 l) was filtered through $1.2 \mu \mathrm{m}$ nominal pore-size glass-fiber filters (147 mm; Gelman GC50), and the bacteria in the filtrate concentrated 10 -fold using a $0.2 \mu \mathrm{m}$ pore-size polycarbonate cartridge filter (Nuclepore). An aliquot (20 ml) of the bacterial concentrate was made up to $2000 \mathrm{ml}$ with virus-free ultrafiltered (Amicon S10Y30 and S1Y30 cartridges; $30000 \mathrm{MW}$ cut-off) seawater made immediately before the experiments as previously described (Suttle et al. 1991). This procedure decreased the concentration of viruses by about 100 fold and bacterial numbers by about 10-fold compared to the in situ abundances. Reducing the abundances of viruses and bacteria decreased contact rates between them, and thereby reduced the production of new viruses by the lytic cycle. Encounter rates between viruses and bacteria were calculated using the model of Murray \& Jackson (1992). Assuming the diameter of 


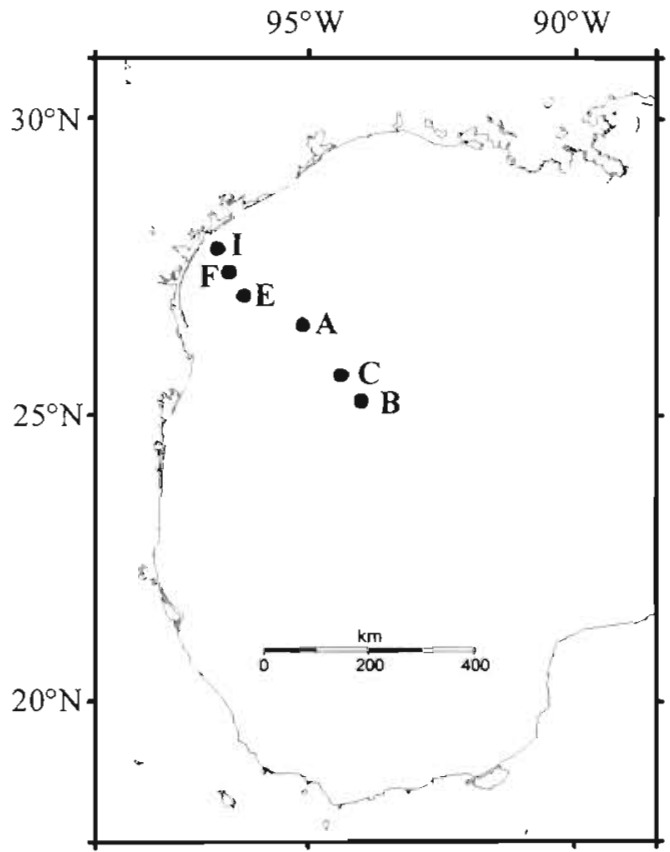

Fig. 1. Location of sampling sites in the western Gulf of Mexico

a typical bacterial cell to be $0.5 \mu \mathrm{m}$, subsequent to dilution $<0.7 \%$ of the bacterial community was contacted per hour by a virus. Therefore, the observed virus production was primarily the result of induction of lysogenized cells rather than lytic infection. Decreasing the viral abundance also allowed viral production to be estimated more accurately by reducing the background concentration of viruses. Furthermore, dilution of the samples with ultrafiltrate minimised the possibility that the experiments were compromised by nutrient limitation of the microbial community.

Aliquots $(200 \mathrm{ml})$ of diluted samples were added to UV-transparent polyethylene bags (Fisher). For the chemical treatments, either mitomycin C (Sigma Chemical Co. No. M-0503; $1 \mathrm{mg} \mathrm{ml}^{-1}$ deionized-distilled water) or hydrogen peroxide (J.T. Baker Chemical No. 2186; $3 \%$ in deionized-distilled water) was added to the incubations at final concentrations of $1.0 \mu \mathrm{g} \mathrm{ml}^{-1}$ or 0.1 to $1.35 \mu \mathrm{M}$, respectively. Samples were also exposed to solar radiation from ca 08:00 to 17:00 $\mathrm{h}$, except for the sample from $\mathrm{E}_{\mathrm{DCM}}$, which was exposed from 12:00 to 17:00 h. Following exposure the samples were kept in the dark. Untreated dark incubations served as controls. Previous studies indicated that there was no difference in viral and bacterial numbers between incubations in the dark and incubations in which UV-B was excluded by Mylar film (Weinbauer \& Suttle 1996). Treatments were performed in duplicate. The bags were placed in a flowing seawater bath to maintain in situ temperature. Subsamples for the enu- meration of viruses and bacteria, and estimation of burst size were removed periodically and preserved with glutaraldehyde ( $2 \%$ final concentration). Untreated incubations were used as controls to check for lytic phage production.

Quantification of bacteria, viruses and chlorophyll a. Bacterial and viral abundances were determined within $19 \mathrm{~d}$ of sample collection. Aliquots of the samples were stained with 4'6-diamidino-2-phenylindole (DAPI; final concentration: $1 \mu \mathrm{g} \mathrm{ml}^{-1}$ ) and enumerated by epifluorescence microscopy (Suttle 1993) using the modifications of Weinbauer \& Suttle (1997). Samples for bacteria and viruses were stained without DNase treatment for $30 \mathrm{~min}$ and filtered onto $0.02 \mu \mathrm{m}$ pore-size Anodisc filters (Whatman) and enumerated using an Olympus BX40 epifluorescence microscope. Chl a was determined fluorometrically (Parsons et al. 1984 ).

Determination of burst size. Bacteria from up to $40 \mathrm{ml}$ of sample were collected quantitatively onto Formvarcoated, 400-mesh electron microscope grids by centrifugation in a swinging-bucket rotor (SW 40; $70950 \times \mathrm{g}$ for $20 \mathrm{~min}$ ). The grids were stained for $30 \mathrm{~s}$ with $1 \%$ uranyl acetate and rinsed 3 times with deionizeddistilled water. The time and speed of centrifugation avoided disruption of infected bacteria. Furthermore, phages within bacteria were easily distinguished as few viruses in solution were pelleted. Burst size was estimated by averaging the number of virus-like particles (VLPs) within a minimum of 15 cells that were completely filled with VLPs (Weinbauer \& Peduzzi 1994).

\section{RESULTS}

\section{Characterisation of sampling sites}

Water temperatures ranged from 21.3 to $28.8^{\circ} \mathrm{C}$ and salinity from 29.3 to $36.6 \mathrm{ppt}$ (Table 1). Chl a at the oceanic stations (A, C, D) ranged from 0.04 to $0.08 \mu \mathrm{g}$ $\mathrm{I}^{-1}$, and at the neritic stations $(E, F, I)$ from 0.21 to $0.38 \mu \mathrm{g} \mathrm{I}^{-1}$. At the oceanic stations bacterial abundances ranged from $0.4 \times 10^{6}$ to $0.6 \times 10^{6} \mathrm{ml}^{-1}$, while viral abundances ranged from $0.2 \times 10^{6}$ to $0.3 \times 10^{6}$ $\mathrm{ml}^{-1}$. At the neritic stations bacteria and viruses were more abundant and ranged from $1.0 \times 10^{6}$ to $3.5 \times 10^{6}$ bacteria $\mathrm{ml}^{-1}$ and from $5.1 \times 10^{6}$ to $8.7 \times 10^{6}$ viruses $\mathrm{ml}^{-1}$.

\section{Bacterial dynamics}

Bacterial abundance typically increased in the controls and sunlight-exposed incubations, but the response was more variable in incubations treated with 
Table 1. Temperature, salinity, chlorophyll a concentrations, bacterial and viral abundances, and burst sizes at the various sampling sites at the different stations. Stn A: $26^{\circ} 44^{\prime} N_{1} 95^{\circ} 19^{\prime} W_{i}$ Stn B: $25^{\circ} 19^{\prime} N_{1} 94^{\circ} 07^{\prime} W_{i}$ Stn C: $25^{\circ} 41^{\prime} \mathrm{N}, 94^{\circ} 31^{\prime} \mathrm{W}_{i}$ Stn E: $27^{\circ} 00^{\prime} \mathrm{N}, 96^{\circ} 14^{\prime} \mathrm{W}_{i}$ Stn F: $27^{\circ} 32^{\prime} \mathrm{N}_{1} 96^{\circ} 45^{\prime} \mathrm{W}_{i}$ Stn I: $27^{\circ} 45^{\prime} \mathrm{N}, 96^{\circ} 51^{\prime} \mathrm{W}$. DCM: deep chlorophyll maximum. Chl a concentrations are integrated over the mixed layer with the exception of Stn $E_{D C M}$. Values for bacteria, viruses and burst size are expressed as means \pm standard deviation of duplicate incubations

\begin{tabular}{|c|c|c|c|c|c|c|}
\hline Str & $\begin{array}{c}\text { Temperature } \\
\left({ }^{\circ} \mathrm{C}\right)\end{array}$ & $\begin{array}{c}\text { Salinity } \\
\text { (ppt) }\end{array}$ & $\begin{array}{c}\text { Chl a } \\
\left(\mu g ~^{-1}\right)\end{array}$ & $\begin{array}{c}\text { Bacteria } \\
\left(10^{6} \mathrm{ml}^{-1}\right)\end{array}$ & $\begin{array}{l}\text { Viruses } \\
\left(10^{6} \mathrm{ml}^{-1}\right)\end{array}$ & $\begin{array}{c}\text { Burst size } \\
\text { (viruses cell-1) }\end{array}$ \\
\hline \multicolumn{7}{|c|}{ Offshore } \\
\hline A & 28.2 & 35.7 & 0.08 & $0.5 \pm 0.03$ & $0.3 \pm 0.03$ & $28 \pm 7.9$ \\
\hline B & 28.2 & 36.6 & 0.04 & $0.4 \pm 0.03$ & $0.3 \pm 0.03$ & $23 \pm 5.1$ \\
\hline C & 28.5 & 36.5 & 0.07 & $0.6 \pm 0.06$ & $0.2 \pm 0.01$ & $15 \pm 5.3$ \\
\hline \multicolumn{7}{|c|}{ Coastal } \\
\hline $\mathrm{E}$ & 28.4 & 30.1 & 0.14 & $1.8 \pm 0.10$ & $5.1 \pm 0.36$ & $40 \pm 9.5$ \\
\hline$E_{D C M}$ & 21.3 & 36.2 & 0.36 & $1.0 \pm 0.11$ & $5.9 \pm 0.53$ & $33 \pm 9.1$ \\
\hline $\mathrm{F}$ & 28.8 & 29.3 & 0.20 & $2.5 \pm 0.19$ & $6.6 \pm 0.40$ & $47 \pm 5.6$ \\
\hline I & 21.1 & 30.6 & 0.35 & $3.5 \pm 0.22$ & $8.7 \pm 0.09$ & $64 \pm 19.1$ \\
\hline
\end{tabular}

hydrogen peroxide. In contrast, abundance remained comparatively stable in incubations treated with mitomycin C (Figs. $2 \& 3$ ). The effect of solar radiation and hydrogen peroxide on bacterial production was estimated from the change in bacterial abundance between the beginning and end of each experiment. At the end of the experiments (about $24 \mathrm{~h}$ ), abun-

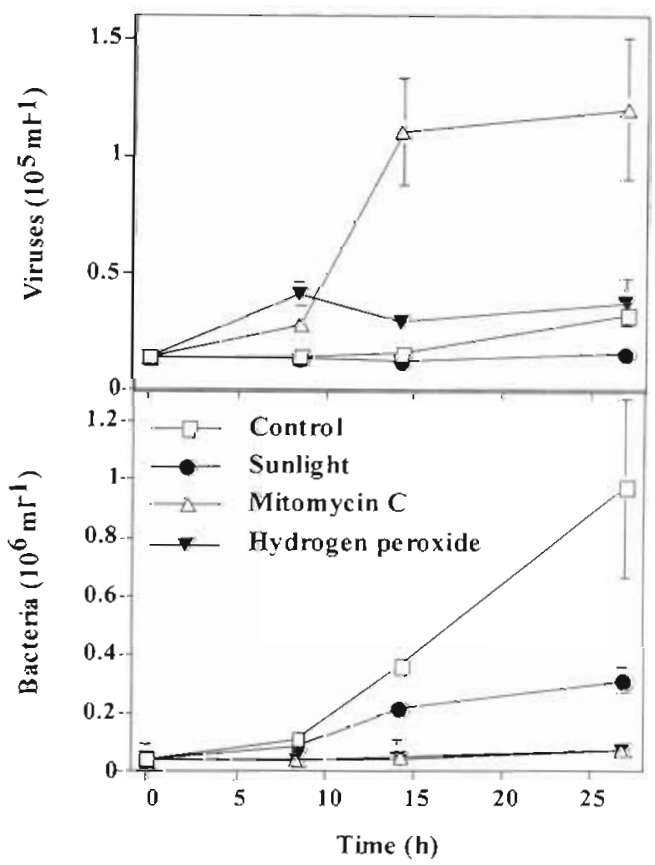

Fig. 2. Virus and bacterial abundances in experiments using seawater collected at an offshore station ( $\operatorname{Stn}$ C) on June 28 , 1995. When error bars are not shown, the range calculated from duplicate incubations was less then the width of the symbols dances in the solar-radiation-treated incubations were 29 to $84 \%$ (average: $55 \pm$ $25 \%, \mathrm{n}=7$ ) of those in the dark controls. Percentages did not differ significantly between neritic and oceanic stations (2tailed $t$-test $t_{i}>0.4$ ). The inhibition of bacterial growth was not correlated significantly to PAR ( $\mathrm{r}=0.430 ; \mathrm{p}>0.3)$. Hydrogen peroxide had an even stronger effect on bacterial production. Bacterial abundances in hydrogen-peroxide treatments were between 3 and $71 \%$ (average: $25 \pm 25 \%, n=7$ ) of those in control incubations. The inhibition of bacterial growth due to hydrogen peroxide was not correlated significantly $(\mathrm{r}=0.284 ; \mathrm{p}>0.5)$ to the hydrogen-peroxide concentration added and did not differ significantly between coastal and oftshore stations (2-tailed $t$ test; $\mathrm{p}>0.8$ ).

\section{Viral dynamics}

Typically, virus abundances remained comparatively stable in the controls during the first 7 to $17 \mathrm{~h}$, but increased when treated with $1.0 \mu \mathrm{g} \mathrm{ml}^{-1}$ mitomycin $\mathrm{C}$ (Figs. 2 \& 3). The difference in viral abundance between mitomycin $\mathrm{C}$-treated and untreated incubations

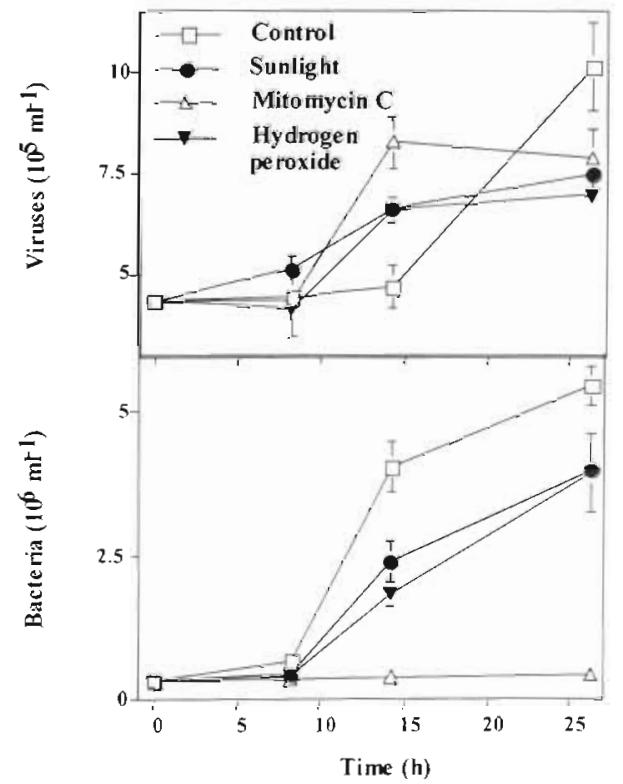

Fig. 3. Virus and bacterial abundances in experiments using seawater collected at a coastal station (Stn F) on November 1. 1995. When error bars are not shown, the range calculated from duplicate incubations was less then the width of the symbols 


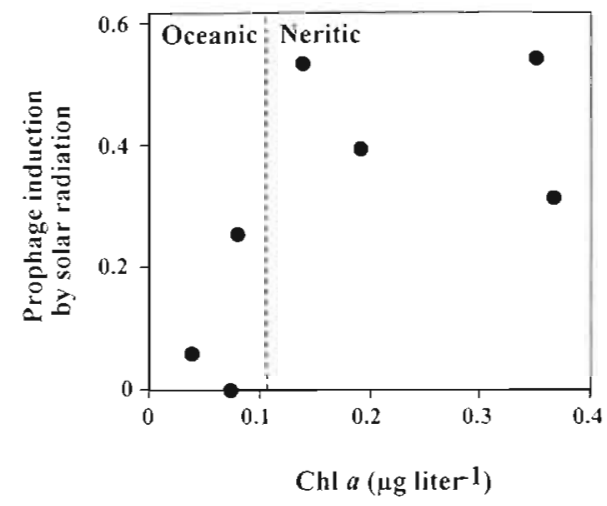

Fig. 4. Prophage induction as the result of exposure to solar radiation relative to that of mitomycin $C$. The effect of solar radiation on prophage induction was calculated using data from Table 2. It is expressed as the ratio of viruses produced in the sunlight-treated incubations to the viruses produced in the mitomycin C-treated incubations

during this period was assumed to have resulted from lysogenic phage production. After this initial period, viral abundances remained comparatively stable in the mitomycin $\mathrm{C}$ treatments, but increased in the control incubations of some experiments.

After 7 to $17 \mathrm{~h}$ of incubation, viral abundances were higher in sunlight-exposed samples than dark controls (except for Stn C); however, the abundances were always lower than in mitomycin C treatments (Figs. 2 \& 3). This indicates that solar radiation induced a portion of the lysogenized bacteria. The ratio of sunlightinduced viral production to that induced by mitomycin

Table 2. Estimation of the percentage of lysogenic bacteria in the total bacterial community based on induction by mitomycin $C . V_{m}$ : viral abundance $\left(\mathrm{ml}^{-1}\right)$ in the mitomycin $C$ treatment; $V_{\mathrm{s}}$ : viral abundance $\left(\mathrm{ml}^{-1}\right)$ in incubations that were exposed to solar radiation from about 08:00 to $17: 00 \mathrm{~h} ; \mathrm{V}_{\mathrm{h}}$; viral abundance $\left(\mathrm{ml}^{-1}\right)$ in the hydrogen peroxide incubations; $V_{c}$ : viral abundance $\left(\mathrm{ml}^{-1}\right)$ in the control incubations. Values for viruses and bacteria are expressed as means \pm range calculated from duplicate incubations. Bacterial abundance is given at the onset of the experiment. Percentage of lysogenic bacteria calculated as $\left[\left(V_{m}-V_{c}\right) / B / A\right\} \times 100$, where $B=$ burst size and $A=$ bacterial abundance

\begin{tabular}{|c|c|c|c|c|c|c|}
\hline Stn & $V_{m}-V_{c}$ & $V_{s}-V_{c}$ & $V_{h}-V_{c}$ & Burst size & $\begin{array}{c}\text { Bacteria } \\
\left(10^{5} \mathrm{ml}^{-1}\right)\end{array}$ & $\begin{array}{c}\text { \% lysogenic } \\
\text { bacteria }\end{array}$ \\
\hline \multicolumn{7}{|c|}{ Offshore } \\
\hline A & 16700 & 4850 & 7980 & $22 \pm 6.2$ & $0.49 \pm 0.025$ & 1.5 \\
\hline B & 10370 & 630 & 4960 & $20 \pm 5.4$ & $0.20 \pm 0.163$ & 2.6 \\
\hline $\mathrm{C}$ & 94420 & 0 & 2640 & $25 \pm 3.5$ & $0.33 \pm 0.053$ & 11.4 \\
\hline \multicolumn{7}{|c|}{ Coastal } \\
\hline $\mathrm{E}$ & 61200 & 19130 & 3520 & $36 \pm 5.9$ & $2.20 \pm 0.962$ & 0.8 \\
\hline $\mathrm{E}_{\mathrm{DCM}}$ & 72900 & 38900 & 3610 & $29 \pm 4.7$ & $2.96 \pm 0.830$ & 0.8 \\
\hline $\mathrm{F}$ & 65580 & 25980 & 9480 & $45 \pm 11.2$ & $1.83 \pm 0.353$ & 0.9 \\
\hline I & 358080 & 194790 & 190370 & $51 \pm 9.7$ & $3.19 \pm 0.229$ & 2.2 \\
\hline
\end{tabular}

C ranged from 0 to 0.54 (average, $0.29 \pm 0.21 ; n=7$ ) and was significantly ( 2 -tailed $t$-test; $\mathrm{p}<0.05$ ) lower at oceanic (average, $0.12 \pm 0.15 ;$ range, 0 to $0.25 ; n=3$ ) than neritic stations (average, $0.42 \pm 0.12$; range, 0.31 to $0.54 ; \mathrm{n}=4$; Fig. 4 ).

Hydrogen-peroxide-induced phage production after 7 to $17 \mathrm{~h}$ was lower than that induced by mitomycin C, but higher than in dark controls (Figs. 1 \& 2), indicating that hydrogen peroxide can induce lysogenic phage production. At Stns $\mathrm{C}, \mathrm{E}$ and $\mathrm{E}_{\mathrm{DCM}}$ the hydrogen-peroxide-induced virus production ranged from 3 to $6 \%$ of that induced by mitomycin $\mathrm{C}$ (calculated from Table 2). At Stn F, it was $15 \%$ of that induced by mitomycin $C$, and ranged from 48 to $53 \%$ at Stns A, B and I. Hydrogen-peroxide-induced phage production was not correlated significantly to the final concentration of hydrogen peroxide $(r=0.313 ; p>0.5)$. At Stns B and C, hydrogen peroxide induced a greater number of viruses than treatment with solar radiation.

\section{Burst size and percentage of lysogenic bacteria}

Estimates of burst size in mitomycin C-treated incubations ranged from 20 to 45 (average: $33 ; \mathrm{n}=7$; Table 2), similar to estimates for untreated natural bacterial communities (15 to 64 , average $36, \mathrm{n}=7$; Table 1). The difference in burst-size estimates between seawater samples and mitomycin C-treated incubations was not significant (2-tailed $t$-test; $p>0.3$ ).

Seven to $17 \mathrm{~h}$ after the start of the experiments, viral abundances were higher in the mitomycin Ctreated incubations than in the controls; the difference was attributed to phage production as a result of lysogen induction. The number of induced bacteria $(\mathrm{N})$ was calculated as $N=\left(V_{m}-V_{c}\right) / B$, where $\mathrm{V}_{\mathrm{m}}=$ viral abundance in mitomycin $\mathrm{C}$ treatments, $V_{c}=$ viral abundance in control incubations and $\mathrm{B}=$ burst size. Burst sizes were determined in samples collected after 7 to $17 \mathrm{~h}$ from the mitomycin $\mathrm{C}$ incubations. The percentage of lysogenic cells in the starting bacterial communities was estimated to range from 1.5 to $11.4 \%$ at the oceanic stations and from 0.8 to $2.2 \%$ at the neritic stations (Table 2). Significantly higher percentages of lysogenized bacteria were found in oceanic than neritic waters during the June cruise, as well as when the data from the June cruise were combined with those collected during a previous study (Weinbauer \& Suttle 1996) (2-tailed t-test; $\mathrm{p}<0.05$ ). 


\section{DISCUSSION}

This study provides empirical estimates of the proportion of lysogenic cells in marine bacterial communities, based on induction by mitomycin C. A higher proportion of cells were induced in oceanic than neritic waters. Solar radiation and hydrogen peroxide also induced lysogenic phage production, although they were not important mechanisms for phage production and bacterial mortality.

\section{Response of bacteria to solar radiation and hydrogen peroxide treatment}

Solar radiation inhibited bacterial production relative to dark incubations. Similar effects on bacterial abundance and production have been observed for other environments (e.g. Herndl et al. 1993, Jeffrey et al. 1996). The effect of solar radiation did not differ significantly between coastal and offshore stations. This is consistent with observations that DNA damage was similar in sunlight-exposed natural viral communities from neritic and oceanic stations (Weinbauer et al. 1999). When compared with solar radiation, hydrogen peroxide had an even more pronounced effect on bacterial production. Even at the lowest concentration added $(0.1 \mu \mathrm{M})$, bacterial abundance was strongly reduced relative to dark incubations. Since hydrogenperoxide concentrations up to $0.2 \mu \mathrm{M}$ are found in the Gulf of Mexico (Van Baalen \& Marler 1966, Zika et al. 1985), it might be important in controlling bacterial biomass and production.

\section{Percentage of lysogenized bacteria}

The data in this paper indicate that 0.8 to $11.4 \%$ (average, $2.9 \% ; \mathrm{n}=7$ ) of the natural bacterial community was induced to produce phage by the addition of mitomycin C (Table 2). Paul and co-workers (Jiang \& Paul 1996, Cochran et al. 1998, Cochran \& Paul 1998) estimated that mitomycin C-induced lysogens in ca 50 to $60 \%$ of the samples they examined. They inferred that the percentage of bacteria that were lysogenized varied from undetectable to $100 \%$. In contrast, we detected low levels of lysogenic phage production in all samples. Our approach can detect induction by $<0.1 \%$ of the bacterial community (Weinbauer \& Suttle 1996); whereas, the lowest percentage of lysogeny detected by Paul and co-workers was $1.3 \%$, a level near or above several samples in our study. Our lower detection level was because reducing virus concentrations decreased the background, and because estimates of viral abundance made by epifluorescence microscopy are more accurate and precise than those made by transmission electron microscopy (Hennes \& Suttle 1995, Weinbauer \& Suttle 1997). If the percentage of lysogens was near zero when Paul and co-workers did not detect lysogenic phage production, then the average percentage of lysogens ranged from ca 5 to $10 \%$. This is only slightly higher than the 2 to $4 \%$ measured in our studies and similar to the 0.1 to $7.4 \%$ estimated by Tapper \& Hicks (1998).

Another approach for estimating the proportion of lysogenic cells is to determine the decrease in bacteria in response to the addition of mitomycin C. Jiang \& Paul (1996) estimated that, on average, 35\% of cells in natural bacterial communities lysed following mitomycin $C$ exposure. However, toxic effects of mitomycin $\mathrm{C}$ may be the reason for the high loss rates of bacteria. It is also possible that chemicals such as polychlorinated biphenols may aiso be effective inducing agents (Cochran et al. 1998). Finally, if many bacteria in aquatic environments are dead (Zweifel \& Hagström 1995) or metabolically inactive (Choi et al. 1996), the percentage of lysogens may be underestimated.

The percentage of inducible lysogens was generally lower in samples collected in coastal than in offshore waters in this study (Table 2) and that of Weinbauer \& Suttle (1996). Similarly, Jiang \& Paul (1994) found that more isolates were lysogenic from oligotrophic than eutrophic environments, and a higher percentage of bacteria could be induced in communities collected offshore than from coastal waters (Jiang \& Paul 1996, Cochran et al. 1998). However, Jiang \& Paul (1996) found the highest percentage of inducible lysogens in estuarine environments. They suggested that because bacterial replication and DNA repair depends on growth, fewer lysogens would be induced at oligotrophic stations where cells would be metabolically less active. In our experiments, bacteria were diluted with ultrafiltered seawater to $10 \%$ of their initial abundance. This resulted in substantial growth during the experiments, suggesting that bacteria were not nutrient limited. Jiang \& Paul (1996) also used a constant burst size to calculate the percentage of lysogenized bacteria. However, estimates of burst size were higher for coastal than offshore waters (Table 2; Weinbauer et al. 1993). Since the number of lysogens is calculated as induced virus production divided by burst size, the use of a constant burst size may underestimate the percentage of lysogens in oligotrophic environments and overestimate them in more productive environments. This might partially explain the difference between the studies. Finally, lysogeny is harder to detect in oligotrophic waters, since a smaller burst size results in less viral production. 
Lenski (1988) argued that lysogeny should be favored in environments with high particle loads, because infectivity of free viruses is destroyed by adsorption. Sunlight also destroys viruses (Suttle \& Chen 1992, Wommack et al. 1996). UV-B penetrated deeper at offshore than at coastal stations, resulting in higher decay rates of infectivity (Wilhelm et al. 1998). Our results support the view that lysogeny will predominate in environments with high destruction rates of free viruses. High loss rates because of particle adsorption in estuaries and solar radiation offshore may explain why the percentage of lysogens is higher in these environments.

\section{Lysogenic phage production and solar radiation}

DNA damage induces SOS repair mechanisms, including activation of protease activity by the RecA protein. In turn, this can initiate the lytic pathway of virus replication in lysogens. UV-B causes DNA damage in marine bacteria (Aas et al. 1996, Jeffrey et al. 1996), and can induce RecA activity (Miller et al. 1995). Thus, the increase in phage production observed in our study as the result of exposure to sunlight may have been caused by activation of RecA and the subsequent induction of lysogens. Others have not found evidence for induction of lysogens when bacterial communities were exposed to solar radiation (Wilcox \& Fuhrman 1994, Jiang \& Paul 1996). This might be the result of the error associated with using transmission electron microscopy to count viruses, as well as the relatively weak effect of sunlight on inducing lysogens (Table 2).

UV-B penetrated deeper offshore than in coastal waters (Wilhelm et al. 1998). However, the formation of cyclopyrimidine dimers in DNA dosimeters deployed at the surface for the solar day did not differ between oceanic and neritic stations (data not shown), indicating similar UV exposure in all surface samples. The ratio of viral production in sunlight-exposed versus mitomycin C-treated samples was lower offshore than in coastal waters. This suggests that damaging wavelengths were less effective at inducing lysogens in waters receiving high doses of solar radiation. Virus particles are vulnerable to destruction by sunlight (Suttle et al. 1993, Wommack et al. 1996), particularly in optically transparent offshore waters (Wilhelm et al. 1998). Consequently, selection should favor prophages that are not induced by sunlight, since they benefit from the DNA repair mechanisms of their hosts. Alternatively, sunlight may be less effective at inducing lysogens offshore, because the higher doses of UV-B may have already induced most of the susceptible prophages.

\section{Lysogenic phage production and hydrogen peroxide treatment}

Virus production was higher in bacterial communities exposed to hydrogen peroxide than in controls, indicating induction of lysogens. In surface waters of the Gulf of Mexico, hydrogen-peroxide concentrations can be as high as $0.2 \mu \mathrm{M}$ (Van Baalen \& Marler 1966 , Zika et al. 1985), and turnover in about a day (Johnson et al. 1989). Rain can increase the concentration more than 10-fold (Cooper et al. 1987). Therefore, the concentrations used in the incubations $(0.1$ to $1.35 \mu \mathrm{M})$ correspond to peak natural levels. Hydrogen peroxide can also result from photochemical degradation of organic matter (Petasne \& Zika 1987, Johnson et al. 1989). Thus, solar radiation not only induces lysogenic phage production by directly damaging the DNA, but also indirectly by the production of hydrogen peroxide.

\section{Bacterial mortality and lysogenic phage production}

A steady-state model was used to estimate the mortality that could result from induction of lysogens. The model assumes that when bacteria divide, 1 daughter cell dies and the other survives to divide again. Therefore, something that kills $50 \%$ of bacteria accounts for $100 \%$ of the mortality (Proctor \& Fuhrman 1990). Bacterial mortality resulting from induction by sunlight or hydrogen peroxide was calculated using burst size and induced viral production (Table 2). The simultaneous induction of lysogens by either solar radiation or hydrogen peroxide would have caused the lysis of a maximum of $1.7 \%$ of the bacterial community, representing $3.5 \%$ of the estimated mortality. Given that about $20 \%$ of bacteria in the sea are infected by viruses (Suttle 1994), induction of lysogens represents a small percentage of the phage-inflicted mortality.

Simultaneous induction of lysogens by sunlight or hydrogen peroxide would also have a modest effect on viral abundance. The viral production if all lysogens were induced was estimated from data in Tables $1 \& 2$. The induced viral production was calculated as the \% of lysogenic bacteria $\times$ bacterial abundance in the undiluted samples $\times$ burst size/100. The viral production was also expressed as a \% of the viral standing stock by dividing the estimated viral production by the viral abundance in the undiluted samples and multiplying by 100 . The number of viruses produced as the result of exposure to sunlight ranged from 0 to $2.0 \times 10^{6}$ phages $\mathrm{ml}^{-1}$, or 0 to $22.2 \%$ (average: $8.8 \%$ ) of the standing stock, respectively (Table 2 ). The range in the number of viruses produced by induction due to hydrogen peroxide was $1.4 \times 10^{4}$ to $1.9 \times 10^{6}$ phages $\mathrm{ml}^{-1}$, or 0.6 to $36.3 \%$ (average: $15.3 \%$ ) of the standing stock, 
respectively. These estimates suggest that lysogenic phage production would only occasionally be an important contributor to total phage production (e.g. when lytic phage production is low). These data are consistent with those of Wilcox \& Fuhrman (1994) who showed that lytic infection rather than induction of lysogenic bacteria was primarily responsible for phage production of in coastal waters of Southern California.

This paper presents estimates of the percentage of lysogens that can be induced by mitomycin $\mathrm{C}$, solar radiation and hydrogen peroxide in marine bacterial communities. Induction of lysogens by sunlight and hydrogen peroxide was not an important cause of bacterial mortality and was unlikely to have contributed significantly to phage production in oceanic and neritic waters. Consequently, the effects that phages have on mortality, nutrient flow and species diversity in these systems appears to depend primarily on the lytic pathway of infection. The data also indicate that higher percentages of bacteria are lysogenized in oligotrophic waters than in more productive coastal waters. If higher abundances of lysogenic bacteria are caused by high loss rates of infectious bacteria, then increases in UV-B because of atmospheric ozone depletion could result in an increase in the frequency of lysogens in bacterial communities. In turn, this would affect the role that viruses play in microbial food webs.

Acknowledgements. The captain and the crew of the 'Longhorn' are gratefully acknowledged for their assistance in collecting the water samples at the offshore stations. We also thank A. Chan, D. R. Garza, K. Rodda, R. Sanchez, S. Short and $S$. W. Wilhelm for help during the cruise. This research was supported by grants from the National Science Foundation (OCE-9415602) and Office of Naval Research (N0001492-5-1676) and by a Erwin-Schrödinger post-doctoral fellowship (J00991-BIO) to M.G.W. provided by the Austrian Science Foundation.

\section{LITERATURE CITED}

Aas P, Lyons MM, Pledger RJ, Mitchell DL, Jeffrey WH (1996) Inhibition of bacterial activities by solar radiation in nearshore waters and the Gulf of Mexico. Aquat Microb Ecol 11:229-238

Ackermann HW, DuBow MS (1987) Viruses of prokaryotes, Vol I. General properties of bacteriophages. CRC Press, Boca Raton

Bratbak G, Thingstad F, Heldal M (1994) Viruses and the microbial loop. Microb Ecol 28:209-221

Choi JW, Sherr EB, Sherr BF (1996) Relation between presence-absence of a visible nucleoid and metabolic activity in bacterioplankton cells. Limnol Oceanogr 41:1161-1168

Cochran PK, Paul JH (1998) Seasonal abundance of lysogenic bacteria in a subtropical estuary. Appl Environ Microbiol $64: 2308-2312$

Cochran PK, Kellogg CA, Paul JH (1998) Prophage induction of indigenous marine lysogenic bacteria by environmental pollutants. Mar Ecol Prog Ser 164:125-133
Cooper WJ, Saltzman ES, Zika RG (1987) The contribution of rainwater to variability in surface ocean hydrogen peroxide. J Geophys Res 92:2970-2980

Fuhrman JA, Suttle CA (1993) Viruses in marine planktonic systems. Oceanography 6:51-63

Gottesman M, Oppenheim A (1994) Lysogeny and prophage. In: Webster RG, Granoff A (eds) Encyclopedia of virology. Academic Press, London, p 814-823

Hennes KP, Suttle CA (1995) Direct counts of viruses in natural waters and laboratory cultures by epifluorescence microscopy. Limnol Oceanogr 40:1050-1055

Herndl GH, Müller-Niklas G, Frick J (1993) Major role of ultraviolet-B in controlling bacterioplankton growth in the surface layer of the ocean. Nature 362:717-719

Imlay JA, Linn S (1987) Mutagenesis and stress responses induced in Escherichia coli by $\mathrm{H}_{2} \mathrm{O}_{2} . \mathrm{J}$ Bacteriol 169: 2967-2976

Jeffrey WH, Pledger RJ, Aas P, Hager S, Coffin RB, von Haven R. Mitchell DL (1996) Diel and depth profiles of DNA photodamage in bacterioplankton exposed to ambient solar ultraviolet radiation. Mar Ecol Prog Ser 137: 283-291

Jiang SC, Pauì JH (1994) Seasonal and diel abundance of viruses and occurrence of lysogeny/bacteriocinogeny in the marine environment. Mar Ecol Prog Ser 104:163-172

Jiang SC, Paul JH (1996) Occurrence of lysogenic bacteria in marine microbial communities as determined by prophage induction. Mar Ecol Prog Ser 142:27-38

Johnson KS, Willason SW, Wiesenburg DA, Lohrenz SE, Arnone RA (1989) Hydrogen peroxide in the western Mediterranean Sea: a tracer for vertical advection. DeepSea Res 36:241-254

Jones AE, Shanklin JD (1995) Continued decline of total ozone over Halley, Antarctica, since 1985. Nature 376: 409-411

Lenski RE (1988) Dynamics of interactions between bacteria and virulent bacteriophage. Adv Microb Ecol 10:1-44

Luria SE, Darnell JE Jr (1967) General virology. Wiley and Sons, New York, p 512

Lwoff A (1952) The nature of phage reproduction. In: Fields $P$, van Heyningen WE (eds) The nature of virus multiplication. University Press, Cambridge, p 149-163

Miller RV, Jeffrey WH, Mitchell DL, Hamissou M, Coffin RB (1995) Correlation of fluctuations in bacterial RecA activity with exposure to DNA-damaging stress in aquatic environments. Annual Meeting of the American Society of Limnology and Oceanography, Reno, NV, p 37

Mitchell DL (1996) Radioimmunoassay of DNA damaged by ultraviolet light. In: Pfeiffer G (ed) Technologies for DNA damage and mutations. Plenum Publishing Corp, New York, p $73-83$

Moebus K (1983) Lytic and inhibition responses to bacteriophages among marine bacteria, with special reference to the origin of phage-host systems. Helgol Meeresunters 36: 375-391

Murray AG, Jackson GA (1992) Viral dynamics: a model of the effects of size, shape, motion and abundance of singlecelled planktonic organisms and other particles. Mar Ecol Prog Ser 89:103-116

Parsons T, Maita Y, Lalli C (1984) A manual of chemical and biological methods for seawater analysis. Pergamon Press, Oxford, p 173

Petasne RG, Zika RG (1987) Fate of superoxide in coastal sea water. Nature 325:516-518

Proctor LM, Fuhrman JA (1990) Viral mortality of marine bacteria and cyanobacteria. Nature 343:60-62

Steward FM, Levin BR (1984) The population biology of bac- 
terial viruses: why be temperate? Theor Popul Biol 26: $93-117$

Suttle CA (1993) Enumeration and isolation of viruses. In: Kemp PF, Sherr BF, Sherr EB, Cole JJ (eds) Handbook of methods in aquatic microbial ecology. Lewis, Boca Raton, p $121-134$

Suttle CA (1994) The significance of viruses to mortality in aquatic microbial communities. Microb Ecol 28:237-243

Suttle CA, Chen F (1992) Mechanisms and rates of decay of marine viruses in seawater. Appl Environ Microbiol 58: $3721-3729$

Suttle CA, Chan AM, Cottrell MT (1991) Use of ultrafiltration to isolate viruses from seawater which are pathogens of marine phytoplankton. Appl Environ Microbiol 57: $721-726$

Suttle CA, Chan AM, Chen F, Garza DR (1993) Cyanophages and sunlight: a paradox. In: Guerrero R, Pedrós-Alió C (eds) Trends in microbial ecology. Spanish Society of Microbiology, Barcelona, p 303-307

Tapper MA, Hicks RE (1998) Temperate viruses and lysogeny in Lake Superior bacterioplankton. Limnol Oceanogr 43: 95-103

Thingstad TF, Heldal M, Bratbak G, Dundas I (1993) Are viruses important partners in pelagic food webs? Trends Ecol Evol 8:209-213

Van Baalen C, Marler JE (1966) Occurrence of hydrogen peroxide in sea water. Nature 211:951

Waldor MK, Mekalanos JJ (1996) Lysogenic conversion by a filamentous phage encoding Cholera toxin. Science 272: $1910-1914$

Weinbauer MG, Peduzzi P (1994) Frequency, size and distribution of bacteriophages in different marine bacterial morphotypes. Mar Ecol Prog Ser 108:11-20

Weinbauer MG, Suttle CA (1996) Potential significance of

Editorial responsibility: Gunnar Bratbak,

Bergen, Norway lysogeny to bacteriophage production and bacterial mortality in coastal waters of the Gulf of Mexico. Appl Environ Microbiol 62:4374-4380

Weinbauer MG, Suttle CA (1997) Comparison of epifluorescence and transmission electron microscopy for counting viruses and bacteria in natural marine waters. Aquat Microb Ecol 13:225-232

Weinbauer MG, Fuks D, Peduzzi P (1993) Distribution of viruses and dissolved DNA along a coastal trophic gradient in the northern Adriatic Sea. Appl Environ Microbiol 59:4074-4082

Weinbauer MG, Wilhelm SW, Suttle CA, Pledger RJ, Mitchell DL (1999) Sunlight-induced DNA damage and resistance in natural viral communities. Aquat Microb Ecol 17: $111-120$

Wilcox RM, Fuhrman JA (1994) Bacterial viruses in coastal seawater: lytic rather than lysogenic production. Mar Ecol Prog Ser 114:35-45

Wilhelm SW, Weinbauer MG, Suttle CA, Jeffrey WH (1998) The role of sunlight in the removal and repair of viruses in the sea. Limnol Oceanogr 43:586-592

Wilson WH, Mann NH (1997) Lysogenic and lytic viral production in marine microbial communities. Aquat Microb Ecol 13:95-100

Wommack KE, Hill RT, Muller TA, Colwell RR (1996) Effects of sunlight on bacteriophage viability and structure. Appl Environ Microbiol 62:1336-1341

Zika RG, Moffett JW, Petasne RG, Cooper WJ, Saltzman ES (1985) Spatial and temporal variations of hydrogen peroxide in Gulf of Mexico waters. Geochim Cosmochim Acta 49:1173-1184

Zweifel UL, Hagström A (1995) Total counts of marine bacteria include a large fraction of non-nucleoid-containg bacteria (ghosts). Appl Environ Microbiol 61:2180-2185

Submitted: October 27, 1998; Accepted: February 12, 1999 Proofs received from author(s): August 3, 1999 